九州大学学術情報リポジトリ

Kyushu University Institutional Repository

Economic Impacts of Agricultural Development on the Donors: A Case Study on the Cerrado Agricultural Development Project in Brazil with JIRCAS, Japan

IT0, Shoichi

Department of Agricultural and Resource Economics, Faculty of Agriculture, Kyushu University : Professor Emeritus

QIAN, Jiarong

Institute of Agricultural Economics and Development, Chinese Academy of Agricultural Sciences

HASSANZOY, Naj ibullah

Department of Agricultural Economics and Extension, Faculty of Agriculture, Kabul University

https://doi.org/10.5109/2339028

出版情報: 九州大学大学院農学研究院紀要. 64 (2)，pp.367-378，2019-09-02. Faculty of Agriculture, Kyushu University

バージョン：

権利関係 : 


\title{
Economic Impacts of Agricultural Development on the Donors - A Case Study on the Cerrado Agricultural Development Project in Brazil with JIRCAS, Japan -
}

\author{
Shoichi ITO ${ }^{1}$, Jiarong QIAN ${ }^{2 *}$ and Najibullah HASSANZOY ${ }^{3}$ \\ Professor Emeritus, Kyushu University, a former professor at the Department of Agricultural and Resource Economics, \\ Faculty of Agriculture, Kyushu University, Fukuoka 819-0395, Japan. \\ (Received May 7, 2019 and accepted May 8, 2019)
}

\begin{abstract}
This research analyzes the returns on the donor's investment on agricultural development as a recipient country. In the case of the Cerrado Agricultural Development in Brazil, which was successfully completed in 2001, Japan invested about 60 billion yen during the 1979 and 2001 period and the production in the area has been growing. In this research, the evaluation of the return on the donor's investment was estimated by assuming that there was no Cerrado agricultural development and the world food market prices were much higher. The results indicate that Japan may have gained returns of as much as 12.4 billion yen through the imports of soybeans, soybean-meal, and soybean-oil. There are many more products being imported to Japan such as corn, livestock products, coffee, etc. which are produced in a large amount in Cerrado and the total merit to Japan should be enormous considering that Japan is the largest food net importer in the world.

Accordingly, the total investment by Japan as a donor may be returned with more value than the total investment during each year over two decades. This indicates that the development project has been a success economically and the benefits go to the recipient country, the donor and the consumers in the rest of the world. This further proclaims, from the global food security point of view, the importance of investment in cases like the Cerrado development. JIRCAS contributed to the Cerrado development, especially the use of newly developed suitable varieties of soybeans in Cerrado. The return to Japan from the JIRCAS' contribution may be significant.
\end{abstract}

Key words: agricultural development, Cerrado in Brazil, foreign aid, return to donors, ODA programs

\section{INTRODUCTION}

Brazil is now the largest net agricultural exporter in the world, surpassing the U.S. The value of the net exports from Brazil increased to 82.9 billion dollars in 2013. This is considerably larger than the U.S.'s 40.1 billion dollars in the same year (MALFS, 2012; USDA, 2013). The base for the increase in agricultural exports is the Cerrado agricultural development project, which started due to the collaborative work between the Brazilian and Japanese governments in the late 1970s (Hongo and Hosono, 2012; Norinchukin, 2008). The first phase of the project began in 1979, followed by the second and the third phases, and was completed in March 2001. The agricultural development in the Cerrado area continued even after the completion of the joint project. Mizobe (2014) reported on the development process of the regional value chain activities focusing on soybeans and soybean products as well as the food industries related to soybean products, which have been growing into a large scale as the agro-industry such as livestock in the areas.

\footnotetext{
Professor Emeritus, Kyushu University, a former professor at the Department of Agricultural and Resource Economics, Faculty of Agriculture, Kyushu University

Institute of Agricultural Economics and Development, Chinese Academy of Agricultural Sciences

Department of Agricultural Economics and Extension, Faculty of Agriculture, Kabul University

* Corresponding author (E-mail: qianjiarong@caas.cn)
}

This project, called the "Japan-Brazil Agricultural Development Project in Cerrado", was initiated between the two governments in September 1979 and lasted over two decades (JICA, 2002). In this project, the Japanese invested as much as 295.2 million dollars (35.1 billion yen) as a loan by JICA and the JBIC's "General project funds" (JICA, 2002, pp.3-8), a 11.7 billion yen loan under the "Cerrado Irrigation and Equipment Loan program" (Ditto, pp.3-5) and 12.5 billion yen loan for the "Goias Electricity Project" (Ditto, pp.4-26) as well as a donation of 4.5 billion yen for technical support, which totalled approximately 60 billion yen. The Brazilian government provided 33.3 billion yen (Ditto, pp.3-5). Furthermore, JIRCAS contributed to the development of new soybean varieties suitable for the Cerrado area.

In Cerrado, the major agricultural products are soybean products, including soybeans, soybean-meal, and soybean-oil, and then corn, cotton, coffee, and meats such as broiler, pork and beef. The major agricultural suppliers in the world up to the mid-1980s were the U.S., Canada, France, Germany, Australia and New Zealand. However, in the 1990s, the agricultural development in the Cerrado area grew rapidly, and Brazil gradually penetrated the global markets, gaining a larger share. Brazil became the largest soybean exporter with a market share of $45 \%$ in 2017, surpassing the U.S., the No. 1 exporter, in 2012. In 2017, Brazil's soybean exports were 69 million tons while the U.S.'s were only 57 million tons (USDA: PSD Online, February 2018). Increases in soybean production led to the expansion of soybean-meal and -oil production, which enhanced 
Brazil's livestock industry. Accordingly, exports of broiler from Brazil reached 4 million tons, securing a global market share of as much as 35\% in 2017, surpassing the U.S.'s exports being slightly over 3 million tons and making Brazil the largest broiler exporter in the world (Ditto).

Such a growth resumed in the 2000s at an even faster speed. The value of the agricultural exports of Brazil exceeded 80 billion dollars in 2011 and 84 billion dollars in 2013 (FAOSTAT, 2018). Because the agricultural imports to Brazil were quite small, the net-export of agricultural products from Brazil was at $\$ 72.5$ billion in comparison to the U.S.'s $\$ 34$ billion, making it the largest net-agricultural exporter in the world (Fig. 1-1). This large trade surplus in agriculture is a strong basis for domestic economic power. The agriculture in Brazil is expected to continue to support the entire Brazilian economy (Nourinchukin, 2008).

Like Brazil, the neighbouring countries such as Argentina and Paraguay have some competitive advantages due to their large areas of suitable land for agriculture and they have been developing their agricultural exports based on soybeans. In Cerrado, there may be still 60 million ha of land waiting for agricultural development. It is expected that Brazil will continue to expand its agricultural production. Because the international grain prices since 2006 have remained at higher level than before, those countries may show the power to act as the key player to influence global grain prices.

As a result of such enormous amounts of investments, many papers on the economic development in those individual regions have been published. However, there are few researches on the returns or benefits for the donors and the rest of the world.

Accordingly, this research attempts to quantitatively evaluate the economic impacts of the Cerrado agricultural development on the global markets and the donors, such as Japan, which is the world's largest food import market, focusing on soybeans, soybean-meal, and soy- bean-oil. Recalling that JIRCAS (Japan International Research Center for Agricultural Sciences) contributed to the project by collaboratively developing new varieties of soybeans with EMBRAPA (The Brazilian Agricultural Research Corporation) and CPAC (Center for Agricultural Research in Cerrado), the basic information is described and the economic significance of the Cerrado agricultural development is quantitatively analyzed in this paper. This research also attempts to identify the economic contribution to the rest of the world due to the increases in the production and export of soybean products from Brazil. Given that international soybean prices have remained at a higher level since 2006, it may be important to estimate how much higher soybean prices would have been if there was no soybean production in Cerrado.

In this paper, starting with the Introduction in the first section, some graphical approaches and theoretical mathematical descriptions are provided as the foundation for estimating the economic impacts in the second section. In the third section, the impacts on the donor, Japan, are estimated using the results from the second section. In the fourth section, the conclusion, the summary of this research and the significance of foreign aid programs, especially in agriculture, are presented.

\section{INCREASES IN PRODUCTION IN THE CERRADO AGRICULTURAL DEVELOPMENT PROJECT}

\section{Evolution of Soybeans, Soybean-meal and -oil Production in Cerrado}

Comparing the soybean production between the Cerrado area and the non-Cerrado area in Brazil, the soybeans were mostly from the non-Cerrado areas (98\%) in the mid-1970s. The soybean area in Cerrado increased gradually until 1990, and increased rapidly afterwards, reaching 7 million ha and surpassing the 6.6 million ha of non-Cerrado area by 1999. The soy-

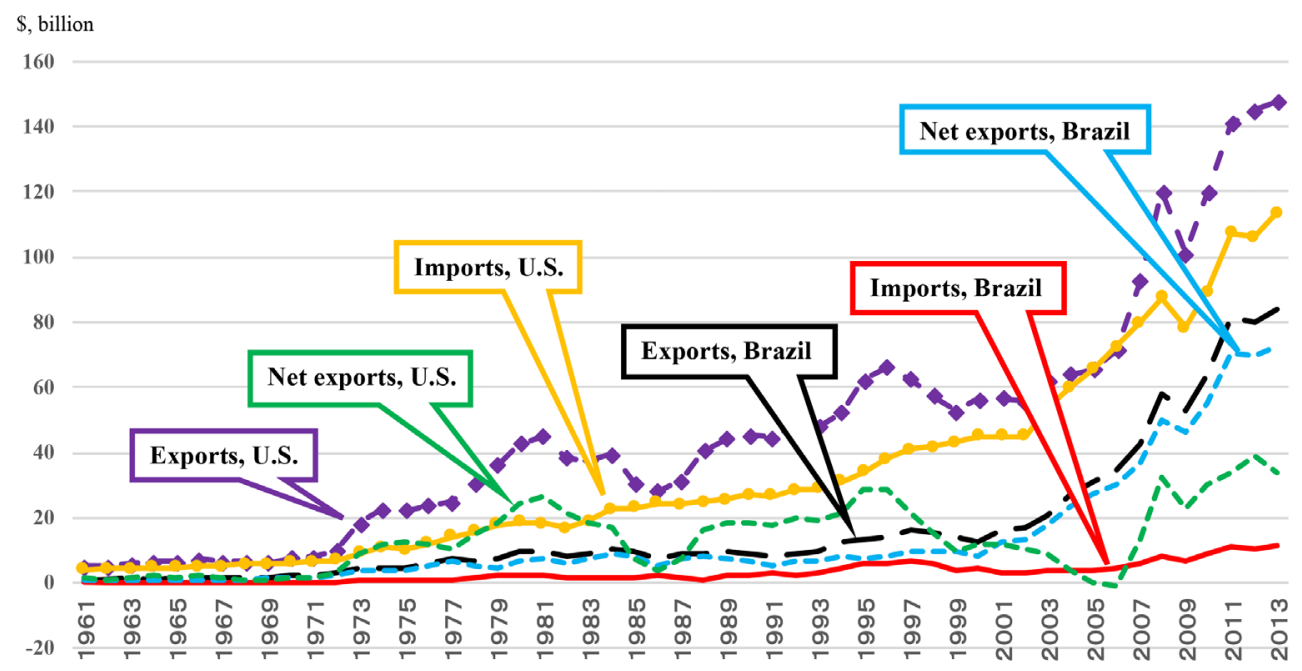

Data sources: FAOSTAT: http://www.fao.org/faostat/en/\#data/TP, January, 2018

Fig. 1-1. Values of agricultural exports, imports, and net exports in Brazil and the U.S., 1961-2013. 
bean area in Cerrado continued to increase, reaching 14 million ha by 2004 and accounting for $60 \%$ of the total soybean area in the nation. It reached 22 million ha with a share of $63 \%$ by 2016 , with a remarkable increase during the last five years (Fig. 2-1).

Regarding the yields for Cerrado and non-Cerrado areas, the yields in Cerrado have been quite stable over time and stayed above the yields of non-Cerrado areas (Fig. 2-2). The actual average yields in 2016 were 3.5 tons and 3.3 tons per ha for Cerrado and nonCerrado areas respectively. This high level of yields in Cerrado reached the same level in the U.S., the world's largest soybean producer. Given that the soil in Cerrado was very poor with a strong acidity which they converted to a more suitable soil for agriculture, it is amazing that the soybean yields in Cerrado reached the level of the U.S.

The production of soybeans is a result of the yield multiplied by the area harvested. Soybean production in Cerrado was less than 10 million MT (metric tons) until around 1990; however, it reached 70 million by 2016, increasing sevenfold in three decades (Fig. 2-3). In non-
Cerrado areas, the soybean production dramatically increased during recent years and reached 44 million MT by 2016. The total soybean production in Brazil in 2016 was 114 million MT, which was slightly less than the U.S.'s by 3 million MT.

Cerrado's share of soybean production was $61.6 \%$ in 2016. Therefore, this rate is applied for soybean-meal and -oil, since the data for those in Cerrado were not available.

\section{Production of soybean-meal and -oil}

Soybean-meal is a by-product of soybeans after subtracting oil and it can be used for many purposes, especially feeding. As soybean production increased, soybean-meal production also increased. It was just above 10 million MT in Brazil in 1990; however, it increased to reach 32 million MT by 2016. The exports of soybeanmeal also increased, reaching 15 million MT in 2016. The export volume was much greater than the U.S.'s 11 million MT. The largest soybean-meal exporter in 2016 was Argentina, at 31 million MT, followed by Brazil.

As stated above, the share data on soybean-meal

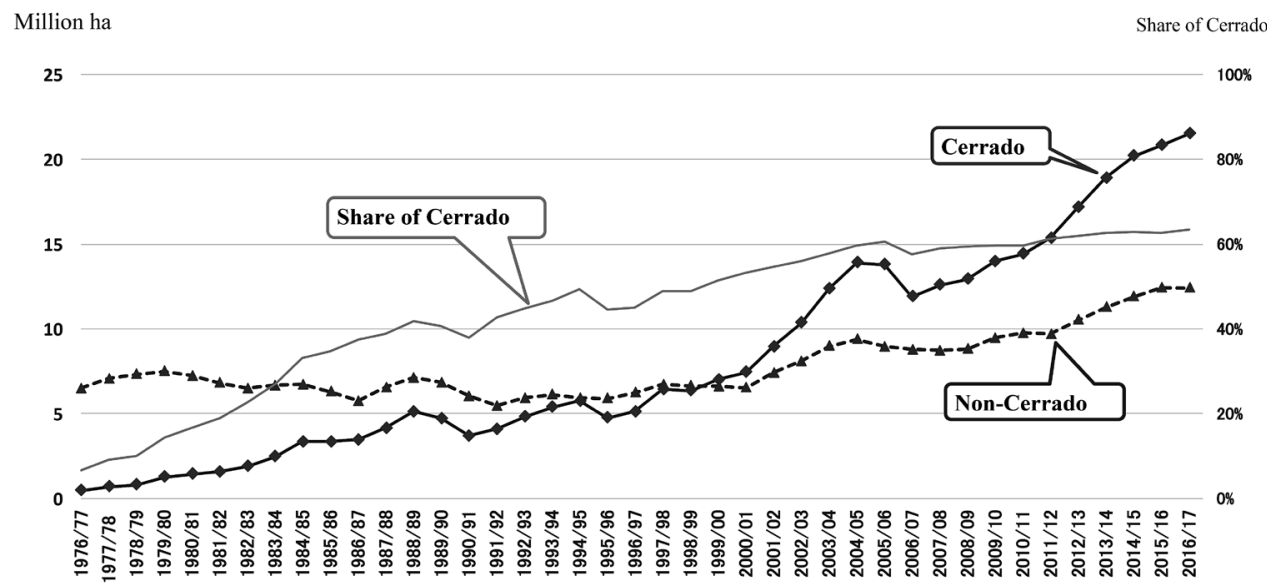

Source: Conab (Companhia Nacional de Abastecimento), http://www.conab.gov.br/ (Visited on December 12, 2017)

Fig. 2-1. Area of soybeans harvested in Cerrado and non-Cerrado 1976 2017.

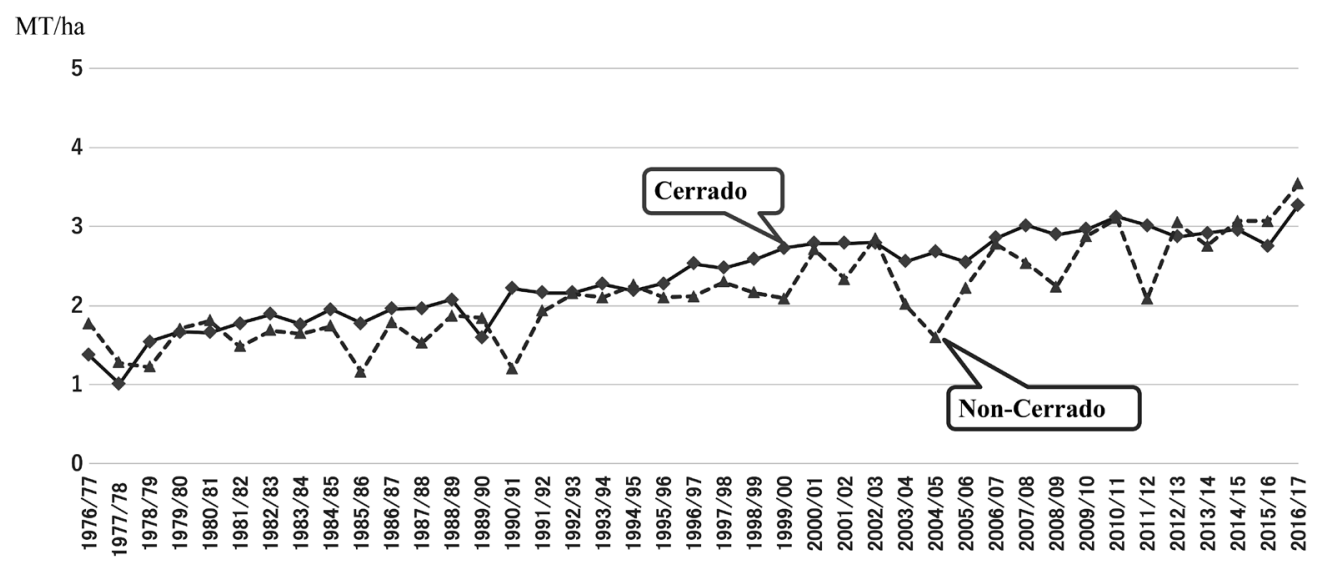

Source: Conab (Companhia Nacional de Abastecimento), http://www.conab.gov.br/ (Visited on December 12, 2017)

Fig. 2-2. Yields of soybeans in Cerrado and non-Cerraco 1976 2017 


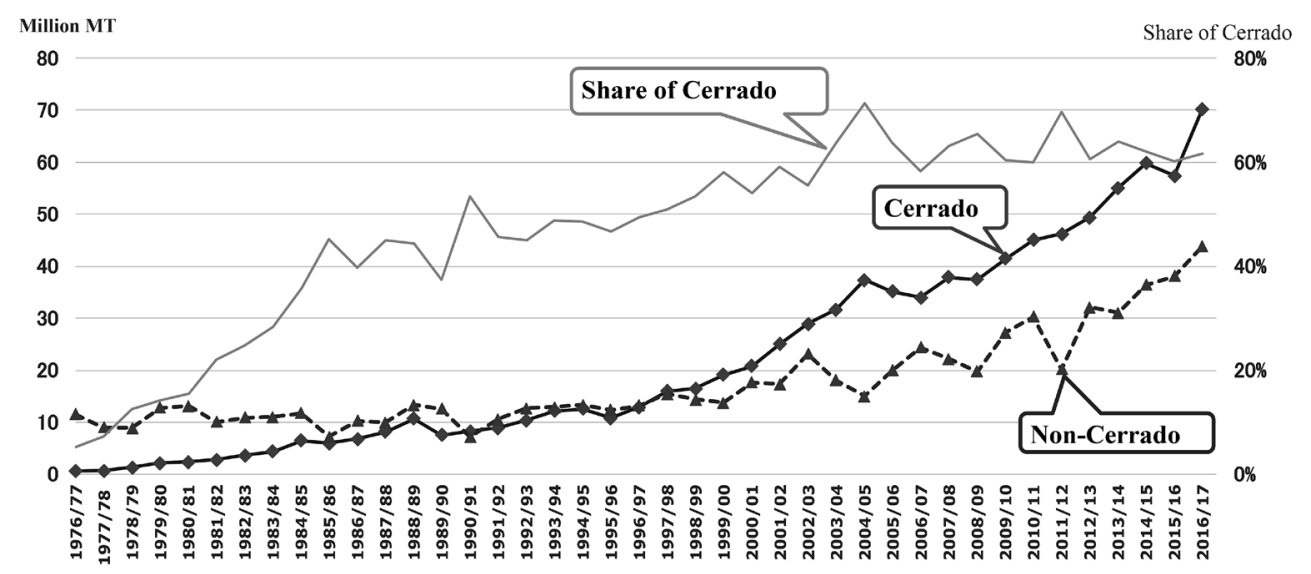

Source: Conab (Companhia Nacional de Abastecimento), http://www.conab.gov.br/ (Visited on December 12, 2017)

Fig. 2-3. Soybean production in Cerrado and non-Cerrado regions in Brazil. 1976 2017.

and -oil were unavailable. Therefore, the shares of soybeans were used to represent the shares of soybeanmeal and -oil in Cerrado and non-Cerrado areas (Fig. 2-4). There may be some leeway; however, it should be minimal. With this share applied, the production of soybean-meal in Cerrado was estimated to be nearly 20 million MT in 2016.

The soybean-oil production in Brazil was about 3 million MT in 1990, then, increased reaching approximately 8 million MT. Soybean-oil in Brazil is used for energy, and as much as $32 \%$ of soybean-oil was used for energy in 2012 (Koizumi, 2014). The amount of soybean-oil used for energy is expected to increase; consequently, exports of soybean-oil from Brazil were slightly over 2.7 million MT in 2012, the largest in history, and it has decreased to 1.5 million MT during the recent years. Applying the same share of soybeans, the production of soybean-oil in Cerrado was approximately 5 million MT in 2016 (Fig. 2-5).

\section{IMPACTS OF PRODUCTION INCREASES IN BRAZIL ON THE GLOBAL MARKETS}

International market prices for agricultural commodities are often quoted from the CBOT (Chicago Board of Trade). While the market prices in Rotterdam, for example, are not independent from those in the CBOT, all the markets in the world correspond with one another every second and the prices are closely related (Ito, et al., 2009). Therefore, the market prices, including those in developing countries, tend to move together, especially among equivalent commodities (Yan, et al., 2015). Accordingly, the prices at CBOT are good indicators of the international market prices.

The increases in agricultural production in Brazil tend to decrease the global market prices. Given this market system, the impacts of increases in soybeans and soybeans related production in Cerrado on the global market are estimated using economic theories and econometric methods.

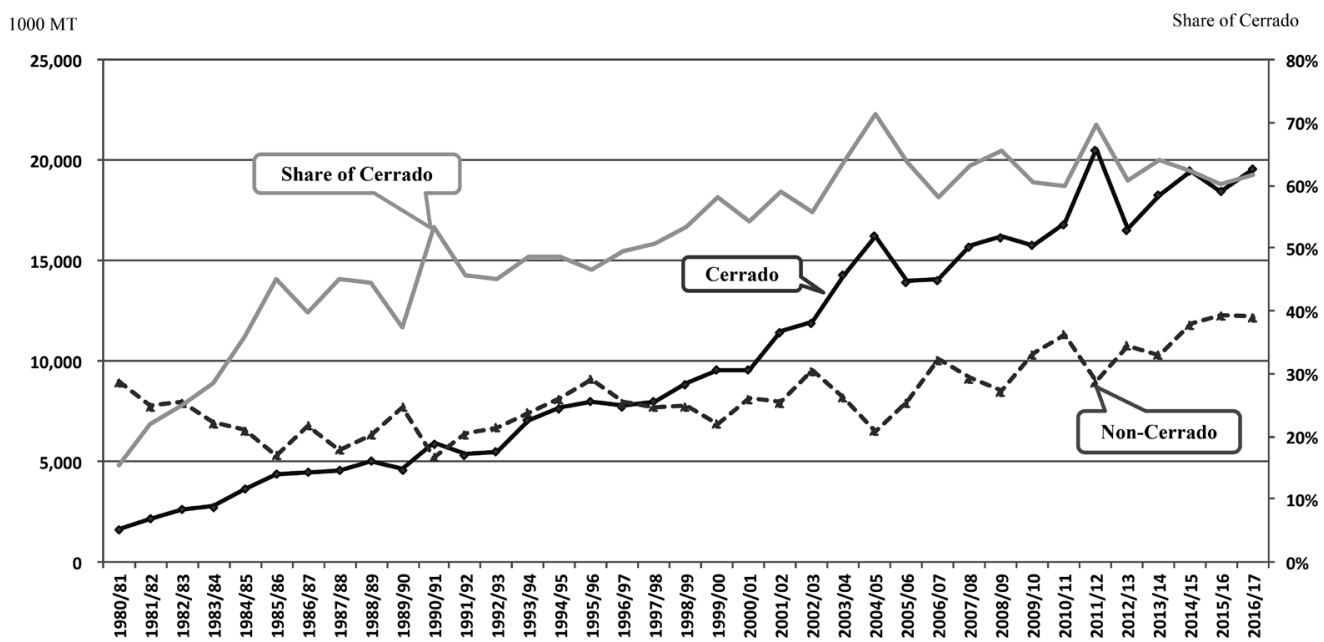

Data sources: USDA: PSD Online, December 2017

Fig. 2-4. Production of soybean-meal in Cerrado and non-Cerrado 1980-2016. 


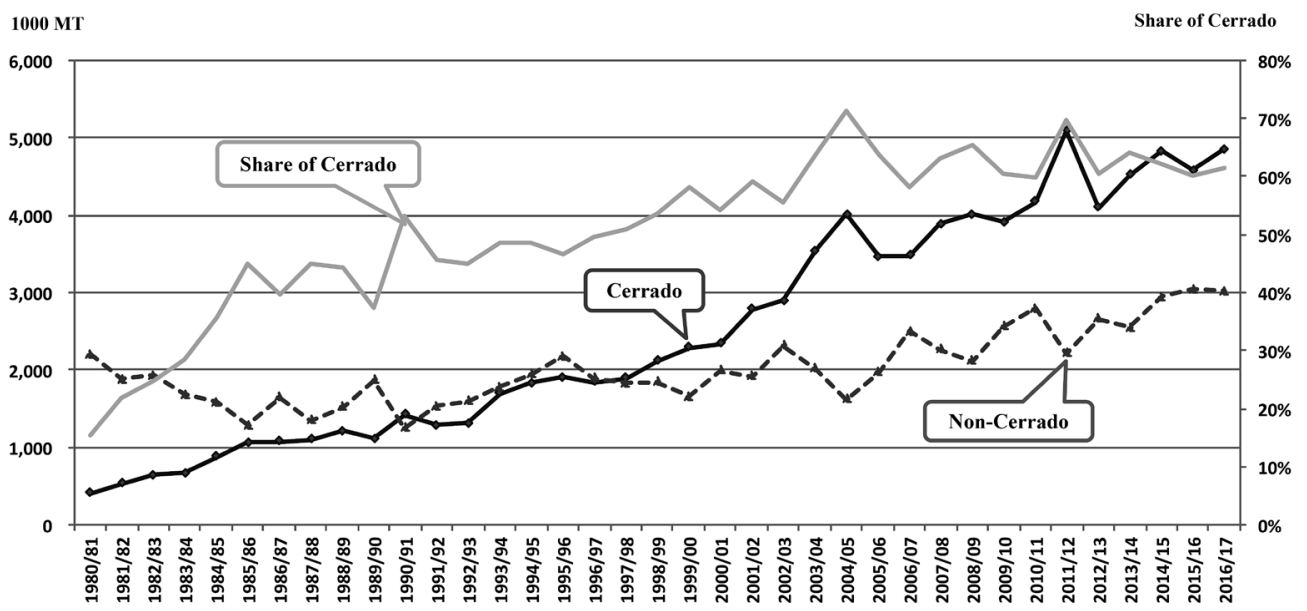

Data sources: USDA: PSD Online, December 2017

Fig. 2-5. Production of soybean-oil in Cerrado and non-Cerrado 1980-2016.

\section{Graphical and Theoretical Approaches}

Fig. 3-1 describes the situations for a case with and without the increases in production in Cerrado. If there were no increases in production in Cerrado, then the supply curve in Fig. 3-1 should be $\mathrm{S}$ with a demand curve, D, and the equilibrium price at E. At this point, the global total production and consumption should be at $\mathrm{q}_{1}$ with the market price at $\mathrm{p}_{1}$. In this case, the consumer surplus is the area, $\mathrm{AEp}_{1}$, and the producer surplus is the area, $\mathrm{BEp}_{1}$. The social surplus is the sum of these two areas.

Next, consider the case where there is a production increase in Cerrado. The supply curve shifts from $\mathrm{S}$ to $\mathrm{S}$ ' and the new equilibrium moves from $\mathrm{E}$ to $\mathrm{E}$ ' with quantity consumed and produced moving to $\mathrm{q}_{2}$ and the price down to $\mathrm{p}_{2}$.

In this case, the consumer surplus is now $\mathrm{AE}^{\prime} \mathrm{p}_{2}$ and the area, $\mathrm{p}_{1} \mathrm{EE} \mathrm{p}_{2}$, which is a gain to the consumers from the increased production or the shift of supply curve to the right. The producer surplus also changes to the area, $\mathrm{p}_{2} \mathrm{E}^{\prime} \mathrm{B}$ '. The social surplus is the area, $A E^{\prime} \mathrm{B}$ ', and this is greater by the area, BEE'B', over the previous situation.

Some mathematical equations which describe the difference in the two situations are as follows:

$$
\mathrm{P}=\phi(\mathrm{QS})
$$

Supply curve before the development, S ----

$\mathrm{P}=\phi^{\prime}\left(\mathrm{Qs} \mathrm{s}^{\prime}\right)$

Supply curve after the development, S'----- (2)

$\mathrm{P}_{\mathrm{i}}=\lambda(\mathrm{QD})$ -Demand curve, D

$\mathrm{VD}=\int_{p 1}^{q 2} Q D d x+\mathrm{q}_{1} p_{1}-q_{2}$

Increased portion of consumer surplus, 1 crop---

$V S=-q_{1} p_{1}+q_{2} p_{2}+\left(\int_{0}^{q 1} Q S d x-\int_{0}^{q 2} Q S^{\prime} d x\right)$ Increased portion of producer surplus, 1 crop --- (5)
The situation above is applicable to the cases of the production of crops, livestock, and etc. where all kinds of products are increased. The summation of all the increased social surplus is the total benefits of agricultural development in Cerrado. To do the summation, the number of products is assumed to be $n(i=1,2, \cdots n)$, and the increased portion of consumer and producer surplus are VD and VS, respectively. The totals of the increased social surplus being summed are $\mathrm{VD}_{\mathrm{g}}$ and $\mathrm{VS}_{\mathrm{g}}$, for consumer and producer surplus, respectively, and described as follows:

$$
\begin{aligned}
& V D_{g}=\sum_{i=1}^{i=n}\left[\int_{q i 1}^{q i 2} Q D_{i} d x_{i}+q_{i 1} p_{i 1}-q_{i 2} p_{i 2}\right] \\
& \text {-------- Accumulation of increased } \\
& \text { consumer surplus, n crops ----- (6) } \\
& V D_{g}=\sum_{i=1}^{i=n}\left[-q_{i 1} p_{i 1}+q_{i 2} p_{i 2}+\left(\int_{q 0}^{q 1} Q S_{i} d x_{i}-\int_{0}^{q 2} Q S_{i}^{\prime} d x_{i}\right)\right] \\
& \text {--------- Accumulation of increased } \\
& \text { producer surplus, n crops ----- (7) }
\end{aligned}
$$

\section{Impacts on global market prices and data}

Generally, the market prices drop as the quantity of product increases and vice versa. The more the increases, the greater the impacts. As Fig. 3-1 shows, increases in production in Cerrado shift the global supply curve to the right with a new equilibrium point at E' with a lower price and greater quantity in the market.

As Ito, et al. (1999) reported in the case of the rice industry in the U.S., many factors are involved, including the improvement of technology over time, and the supply curve get shifted outward. All those factors contribute to shifting the supply curve to the right. With an understanding of the situation, an econometric analysis was conducted.

For a regression analysis, the variables for global prices are put on the left-hand side as the dependent variables, while the global production and other variables put on the right-hand side as explanatory variables. In fact, the market prices of soybeans, soybean-meal and soybean-oil were used as dependent variables while the 
Table 2-1. Production of soybeans in Cerrado and non-Cerrado areas in Brazil, 1976-2017. (Million tons)

\begin{tabular}{|c|c|c|c|}
\hline Years & Cerrado & Non-Cerrado & $\begin{array}{c}\text { Shares of } \\
\text { Cerrado (\%) }\end{array}$ \\
\hline 1976/77 & 0.635 & 11.510 & 5.2 \\
\hline 1977/78 & 0.715 & 9.011 & 7.4 \\
\hline 1978/79 & 1.270 & 8.930 & 12.5 \\
\hline 1979/80 & 2.108 & 12.780 & 14.2 \\
\hline 1980/81 & 2.386 & 13.099 & 15.4 \\
\hline 1981/82 & 2.825 & 10.066 & 21.9 \\
\hline 1982/83 & 3.606 & 10.927 & 24.8 \\
\hline 1983/84 & 4.361 & 10.979 & 28.4 \\
\hline $1984 / 85$ & 6.511 & 11.701 & 35.8 \\
\hline 1985/86 & 5.959 & 7.249 & 45.1 \\
\hline 1986/87 & 6.767 & 10.304 & 39.6 \\
\hline 1987/88 & 8.149 & 9.978 & 45.0 \\
\hline 1988/89 & 10.630 & 13.299 & 44.4 \\
\hline 1989/90 & 7.517 & 12.585 & 37.4 \\
\hline 1990/91 & 8.206 & 7.189 & 53.3 \\
\hline 1991/92 & 8.856 & 10.563 & 45.6 \\
\hline 1992/93 & 10.362 & 12.681 & 45.0 \\
\hline 1993/94 & 12.202 & 12.857 & 48.7 \\
\hline 1994/95 & 12.586 & 13.348 & 48.5 \\
\hline 1995/96 & 10.818 & 12.372 & 46.6 \\
\hline 1996/97 & 12.943 & 13.217 & 49.5 \\
\hline 1997/98 & 15.933 & 15.437 & 50.8 \\
\hline 1998/99 & 16.425 & 14.340 & 53.4 \\
\hline 1999/00 & 19.105 & 13.785 & 58.1 \\
\hline 2000/01 & 20.790 & 17.642 & 54.1 \\
\hline 2001/02 & 24.961 & 17.269 & 59.1 \\
\hline 2002/03 & 28.929 & 23.088 & 55.6 \\
\hline 2003/04 & 31.691 & 18.102 & 63.6 \\
\hline $2004 / 05$ & 37.304 & 15.001 & 71.3 \\
\hline 2005/06 & 35.090 & 19.938 & 63.8 \\
\hline 2006/07 & 33.994 & 24.397 & 58.2 \\
\hline 2007/08 & 37.904 & 22.113 & 63.2 \\
\hline 2008/09 & 37.440 & 19.726 & 65.5 \\
\hline 2009/10 & 41.456 & 27.233 & 60.4 \\
\hline 2010/11 & 45.071 & 30.254 & 59.8 \\
\hline 2011/12 & 46.222 & 20.161 & 69.6 \\
\hline 2012/13 & 49.389 & 32.111 & 60.6 \\
\hline 2013/14 & 55.084 & 31.037 & 64.0 \\
\hline 2014/15 & 59.785 & 36.443 & 62.1 \\
\hline 2015/16 & 57.331 & 38.104 & 60.1 \\
\hline 2016/17 & 70.254 & 43.822 & 61.6 \\
\hline
\end{tabular}

Data sources: Conab (Companhia Nacional de Abastecimento), (Visited on December 12, 2017) http://www.conab.gov.br/

respected volumes of global production and crude oil prices were used as explanatory variables (Ito, et al., 2009). The model and the data sources are as follows:

$$
\mathrm{P}_{\mathrm{it}}=f\left(\mathrm{QS}_{\mathrm{it}-1}, \mathrm{PO}_{\mathrm{t}}, \mathrm{X}_{\mathrm{ijt}}\right)
$$

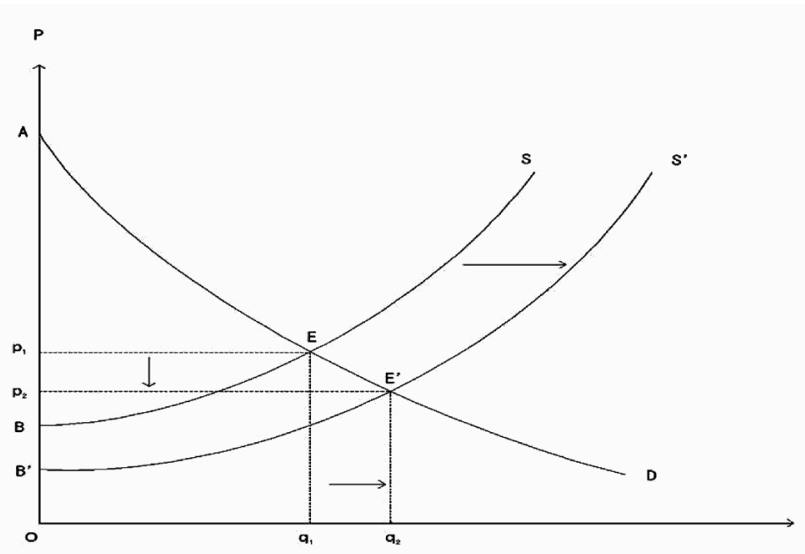

Fig. 3-1. The relationship between production increases and the prices in the international markets.

where,

$\mathbf{P}_{\mathrm{i}}=$ World prices for the i-th commodity, \$/ton, deflated by CPI (from Nikkei Shimbun) to make them real prices; Data sources: USDA publications and CBOT,

$\mathbf{Q s}_{\mathbf{i}}=$ World total production of the i-th commodity, 1000 tons; Data source: USDA: PSD Online,

PO = Crude oil prices (WTI), \$/barrel, also deflated by CPI for real prices; Data source: New York Mercantile Exchange,

$\mathbf{X}_{\mathbf{j}} \quad=$ Other variables and $\mathrm{j}=1,2, \ldots . \mathrm{j}$

i $\quad=1,2, \ldots n$, commodities; for soybeans, soybeanmeal and -oil,

$\mathbf{t}=1990-2016$, annual time series data.

Using the model, the equations for soybeans, soybean-meal and -oil were analyzed. As indicated above, soybean-meal and -oil are by-products of soybeans, and the three prices are closely related to one another (Fig. 3-5). Accordingly, the three equations were estimated using the SUR (Seemingly Unrelated Regression). Furthermore, the variables were transformed to the log form; therefore, the estimated coefficients are all elasticities.

\section{Data}

The commodity prices, except for crude oil, are from the International Monetary Fund's (IMF's) Primary Commodity Prices: http://www.imf.org/external/np/res/ commod/index.aspx. The data on the global production are from the USDA's PSD Online (December 2017), and the crude oil prices are from the New York Mercantile Exchange (NYMX) WTI (West Texas Intermediate). Note that the data of PSD Online, WTI and the US CPI are from Ito (2017): http://worldfood.apionet.or.jp/

The data of Cerrado are from IBGE (2017): http:// www.sidra.ibge.gov.br/

All the price data were converted to real prices using the US CPI (Figs. 3-2, 3-3, and 3-4). All the real price data are compared in one figure (Fig. 3-5). 


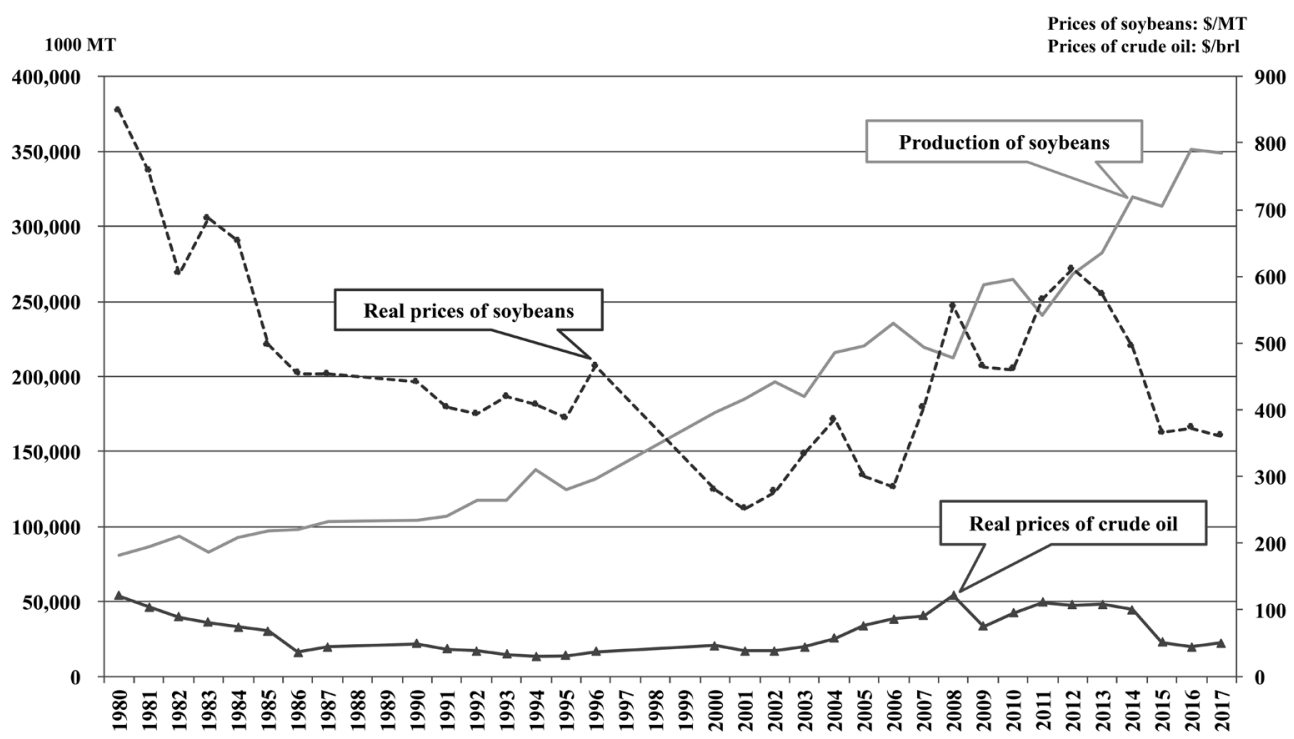

Data sources: IMF: Primary Commodity Prices, Visited on December 22, 2017

http://data.imf.org/?sk=471DDDF8-D8A7-499A-81BA-5B332C01F8B9

USDA: PSD Online, December 2017

Fig. 3-2. Global soybean production and real prices, and crude oil real prices 1980-2017.

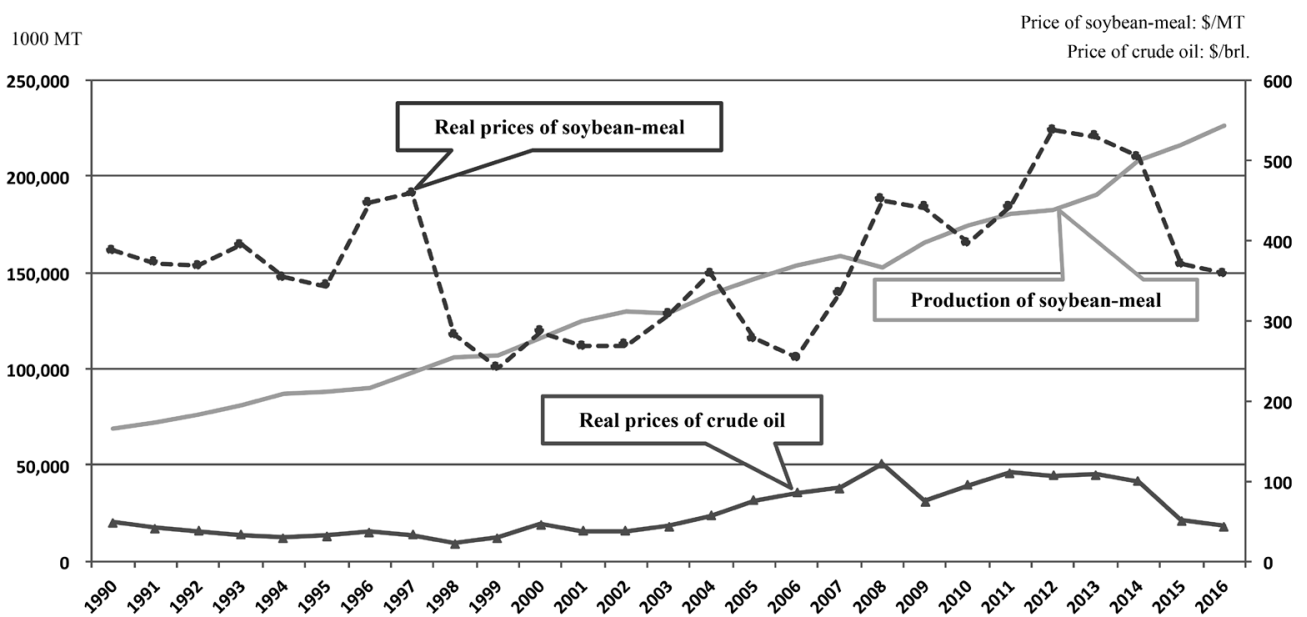

Data sources: IMF: Primary Commodity Prices, Visited on December 22, 2017 http://data.imf.org/?sk=471DDDF8-D8A7-499A-81BA-5B332C01F8B9 USDA: PSD Online, December 2017

Fig. 3-3. Global soybean-meal production and real prices, and crude oil real prices 1990-2016.

\section{Results of the SUR}

The estimated results of the SUR (Seemingly Unrelated Regression) are reported in Table 3-1. The estimated coefficients for the global production are negative as expected, indicating that the market prices decline as production increases. The estimated coefficients are all significant statistically at the $1 \%$ level.

The estimated coefficients are elasticities since the variables are all in the $\log$ form at $-0.414,-0.383$, and -0.441 for soybeans, soybean-meal, and -oil, respectively. In the case of soybeans, if the global production increases by $10 \%$, then the global market prices would decline by $4.14 \%$ with everything else remaining the same.
The relationships between the three commodities and crude oil prices may be dependent on the characteristics of each commodity. Since corn has become a source of energy like ethanol, crude oil and grains have become indirect substitutes. Therefore, the market prices of grains and soybeans often move closely together (Ito, et al., 2009). The daily data clearly show the closely related movement and this should hold true for monthly and annual data.

Oil prices are influenced by speculation on the market. Therefore, the prices of soybeans and related products are influenced by speculation, also. In this research, the estimated elasticities with a high significance level were found, indicating that the prices of soy- 


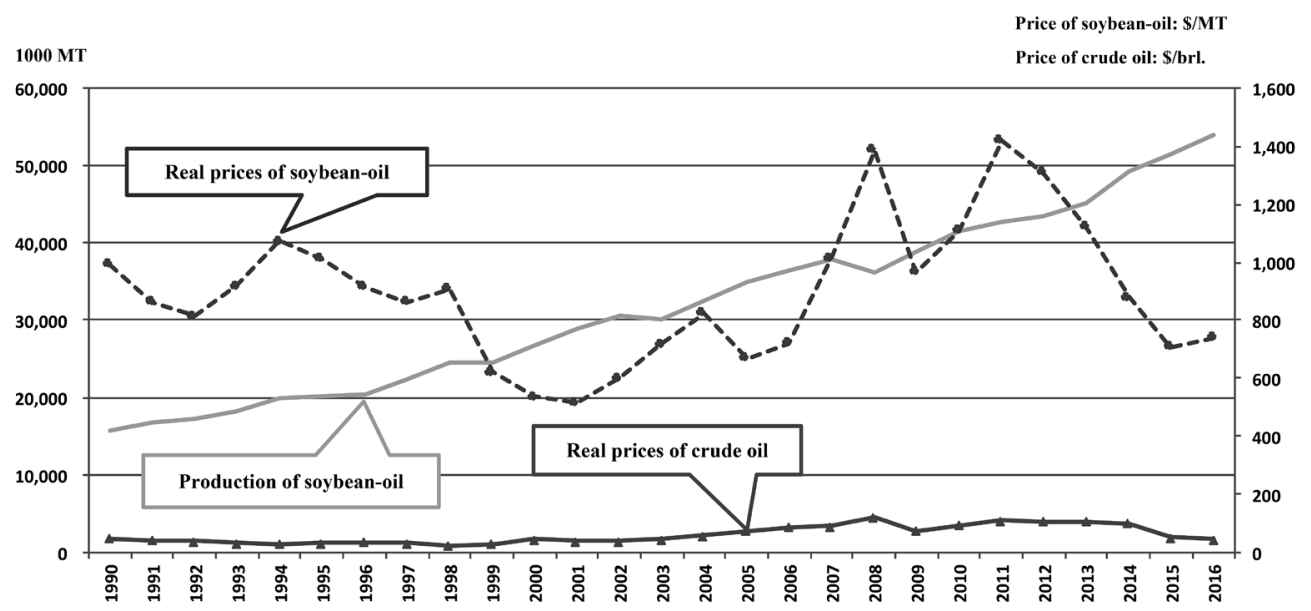

Data sources: IMF: Primary Commodity Prices, Visited on December 22, 2017 http://data.imf.org/?sk=471DDDF8-D8A7-499A-81BA-5B332C01F8B9 USDA: PSD Online, December 2017

Fig. 3-4. Global soybean-oil production and real prices, and crude oil real prices 1990-2016.

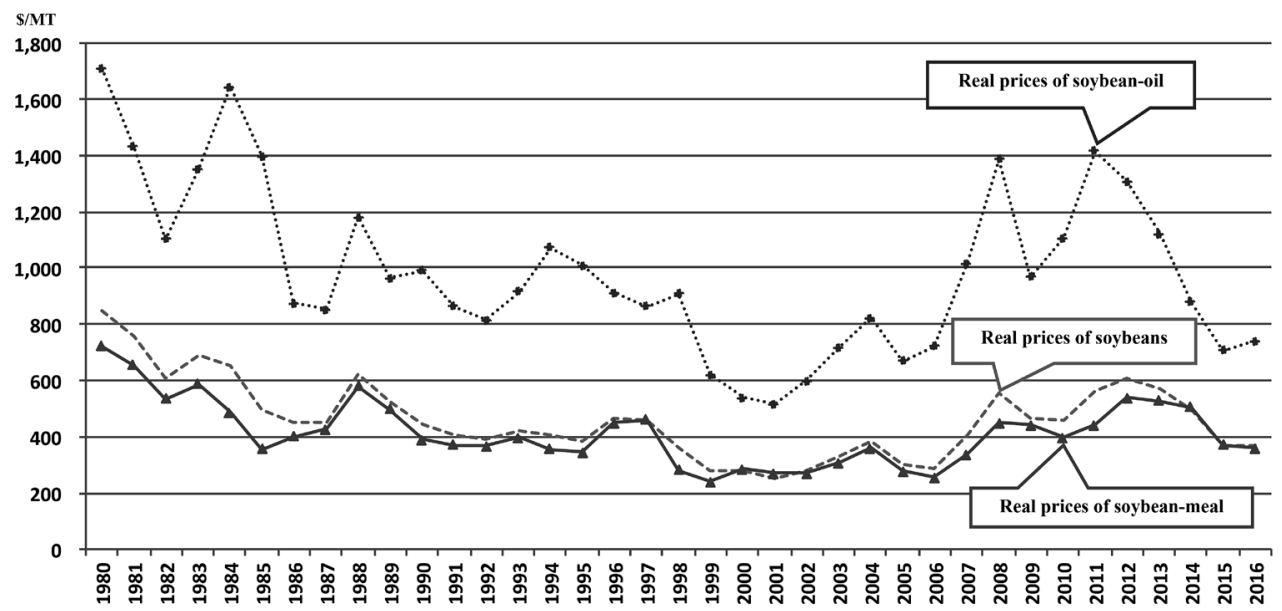

Data sources: IMF: Primary Commodity Prices, Visited on December 22, 2017 http://data.imf.org/?sk=471DDDF8-D8A7-499A-81BA-5B332C01F8B9

Fig. 3-5. Real prices of soybeans, soybean-meal and -oil 1980-2016.

beans and soybean products have a strong relationship with crude oil prices. The estimated coefficients on crude oil prices are at the 5\%,10\% and 1\% significance levels for soybeans, soybean-meal and -oil, respectively, and everything else are at the $1 \%$ significance level (Table 3-1). This strongly indicates that the estimated coefficients are quite reliable.

\section{CALCULATING IMPACTS ON GLOBAL PRICES USING THE ESTIMATED ELASTICITIES}

\section{Shares of Brazil and Cerrado in global production}

In this section, the impacts are estimated using the estimated elasticities in this research to compare the case with and without Cerrado production. Therefore, it is first necessary to determine the share of Cerrado production relative to the total production in Brazil. The results are reported in the first column in Table 4-1. As shown above in Fig. 2-3, 2-4, and 2-5, the production of soybeans, soybean-meal and -oil in Cerrado is at a share of $62 \%$ nowadays relative to the total in Brazil.

Based on those situations, share of Cerrado in global production was calculated: the shares may be $20 \%, 9 \%$, and $9 \%$ for soybeans, soybean-meal and -oil, respectively (the last column in Table 4-1).

\section{Economic gains from agricultural development in Cerrado}

A scenario without agricultural development in Cerrado should delete the volume of actual production in Cerrado from the global total production. In this scenario, the global market prices should surely increase. How much would the global market prices increase? The results are reported in Table 4-2. 
Table 3-1. Results of SUR estimates for soybeans, soybean-meal and -oil

\begin{tabular}{|c|c|c|c|}
\hline & Soybeans & Soybean-meal & Soybean-oil \\
\hline Intercepts & $\begin{array}{c}10.1^{* * * *} \\
(9.23)\end{array}$ & $\begin{array}{c}9.73 * * * \\
(8.11)\end{array}$ & $\begin{array}{c}10.1^{* * * *} \\
(7.84)\end{array}$ \\
\hline Qs: Production & $\begin{array}{c}-0.414^{* * * *} \\
(-4.31)\end{array}$ & $\begin{array}{c}-0.383 * * * \\
(-3.48)\end{array}$ & $\begin{array}{c}-0.441 * * * \\
(-3.23)\end{array}$ \\
\hline PO: Oil prices & $\begin{array}{c}0.179 * * \\
(2.42)\end{array}$ & $\begin{array}{l}0.127^{*} \\
(1.67)\end{array}$ & $\begin{array}{c}0.266^{* * * *} \\
(2.66)\end{array}$ \\
\hline Dummy, '08 -'17 & $\begin{array}{c}0.414^{* * * *} \\
(5.07)\end{array}$ & $\begin{array}{c}0.434 * * * \\
(5.05)\end{array}$ & $\begin{array}{c}0.353 * * * \\
(3.15)\end{array}$ \\
\hline $\mathrm{R}^{2}$ & 0.67 & 0.63 & 0.53 \\
\hline No. of Obs. & 27 & 27 & 27 \\
\hline
\end{tabular}

Note 1: The dependent variables are commodity prices. Numbers in parentheses are t-values.

Note 2: Oil prices are used for the whole period to reflect the use of grains and soybeans for energy. Dummy variables are for the year 2008 when the global food prices surged.

Note $3: * * *, * *$, and $*$ represent $1 \%, 5 \%$, and $10 \%$ significance levels, respectively.

Table 4-1. Share of agricultural production in Brazil and Cerrado, 2016

\begin{tabular}{|c|c|c|c|c|c|}
\hline & $\begin{array}{c}\text { Shares of } \\
\text { Cerrado in } \\
\text { Brazil/1 }\end{array}$ & $\begin{array}{c}\text { Global } \\
\text { production/2 } \\
1000 \mathrm{MT}\end{array}$ & $\begin{array}{c}\text { Production in } \\
\text { Brazil/2 } \\
\text { 1000MT }\end{array}$ & $\begin{array}{c}\text { Shares of } \\
\text { Brazil }\end{array}$ & $\begin{array}{c}\text { Shares of } \\
\text { Cerrado to the } \\
\text { world }\end{array}$ \\
\hline Soybeans & $61.6 \%$ & 351,254 & 114,389 & $33 \%$ & $20 \%$ \\
\hline Sybn Meal & $61.6 \%$ & 226,423 & 31,730 & $14 \%$ & $9 \%$ \\
\hline Sybn Oil & $61.6 \%$ & 53,949 & 7,870 & $15 \%$ & $9 \%$ \\
\hline
\end{tabular}

Sources: /1: IGBE in Brazil. The amounts of shares are considered to be the same for all. /2: USDA, PSD Online for 2016.

On the top two rows of Table 4-2, the estimated elasticities and the shares of production in Cerrado are copied from the previous tables. The next row shows the market prices per MT for soybeans, soybean-meal and -oil in 2016. Below this row, the estimated increases in prices as percentages in a scenario where there was no production in Cerrado are shown. They were calculated from the elasticities multiplied by the shares of Cerrado. The next row shows the estimated increases in the global market prices per MT assuming that there was no production in Cerrado. These are calculated from the multiplication of the two numbers above. The next row is for the actual Japanese imports in 2016. The second row from the bottom shows the results of multiplying the two numbers above, indicating the estimated economic gain from the production in Cerrado, namely the benefits from the agricultural development in Cerrado.

The estimated economic gain should be the additional value that Japan would have to pay if there was no development in Cerrado. In reality, there was an enormous amount of production development in Cerrado; therefore, Japan did not have to pay additional costs. The rest of the world received such a gain as well.

The results indicate that Japan gained as much as 10.3 billion yen from the 3.17 million MT of soybean imports or 95.4 million dollars at an exchange rate of 107.84 yen per US dollar in 2016. From the soybean- meal imports, the total imported volume was 1.62 million MT and Japan got 2.1 billion yen of gains, and the soybean-oil with 5,000 MT imports and 1.5 million yen of gains. While the benefits from the small amount of imports like soybean-oil were relatively small, the benefit from the large amount of imports, like soybeans and soybean-meal, was as large as 12.4 billion yen.

\section{CONCLUSIONS}

The benefits indicated in the previous section were only for the situation in 2016. This type of benefit is not just for 2016 and has been occurring since the mid1990s when the Cerrado development project got on the way and production increased fast. This continues and will possibly continue into the future.

Furthermore, this benefit is not limited to the ones from soybeans, soybean-meal and -oil, but it extends to livestock, which are fed soybean-meal, and to the production of broiler, pork, beef, milk, cheese, and etc. Mizobe (2014) reported the value-chain with different stages focusing on broiler industry in Cerrado. According to his paper, in the case of the western area of the State of Behier in Cerrado, production of soybeans was 3.63 million MT with 0.46 billion dollars for soybeanmeal; however, the total value up to the broiler was as much as 17.87 billion dollars, indicating that a small 
Table 4-2. Economic impacts of agricultural development in Cerrado, Brazil and benefit to Japan in 2016

\begin{tabular}{lccc} 
& Soybeans & Soybean-meal & Soybean-oil \\
\hline Estimated elasticities & -0.414 & -0.383 & -0.441 \\
Share of products in Cerrado & $20 \%$ & $9 \%$ & $9 \%$ \\
Global prices in 2016, \$/MT & 363 & 350 & 721 \\
$\begin{array}{l}\text { Increases in global prices if no } \\
\text { production in Cerrado, \% }\end{array}$ & $8.28 \%$ & $3.45 \%$ & $3.97 \%$ \\
$\begin{array}{l}\text { Increases in global prices if no } \\
\text { production in Cerrado, } \$ \text { MT }\end{array}$ & 30.06 & 12.06 & 28.62 \\
Imports to Japan, 1000MT & 3,175 & 1,621 & 5 \\
\hline $\begin{array}{l}\text { Grains to Japan from ag. } \\
\text { Development in Cerrado, } \$ \text { /MT }\end{array}$ & 95.4 & 19.6 & 0.143 \\
\hline $\begin{array}{l}\text { Ditto, in Japanese yen, } \\
\text { billion yen, } 107.84 \text { yen/USD }\end{array}$ & 10.3 & 2.1 & 0.0154 \\
\hline
\end{tabular}

Sources:/1: Actual volume in 2016, USDA: PSD Online, December 2017

/2: Average rate in 2016 http://www.murc-kawasesouba.jp/fx/yearend/index.php?id=2016

amount of soybean-meal can generate an enormous amount of value, like approximately 40 times as much as the value of the feed. We should not confine this generated value to the State, instead we should expand our consideration of this and understand that it has been occurring almost everywhere in Cerrado with every type of livestock.

The soybeans cannot be planted continuously on the same land due to increased susceptibility to diseases; therefore, crop rotation with other crops such as corn or cotton, etc. is necessary. Due to soil improvement technology in Cerrado, coffee and fruits have become suitable for production in the area and their production is quite significant now. The coffee in Cerrado accounts for more than half of the total production in Brazil, the largest coffee producer in the world. (Note that the benefits from the coffee and other kinds of production in Cerrado are evaluated in the Appendix of this paper.) The Cerrado agricultural development project has made it possible to produce so many crops and livestock products. One should not neglect the indirect benefits to the entire society of the labour employment developing new cities and communities.

Before the Cerrado project, this research found that there were some pioneering farmers who challenged production in Cerrado. However, it is rather natural to imagine that they must have obtained the new technology developed jointly by JIRCAS, EMBRAPA, and CPAC. Therefore, it is not unreasonable to expect that JIRCAS contributed to those pioneering farmers as well.

As described above, the Cerrado agricultural development project was initiated by both Japanese and Brazilian governments under the name PRODECER (JICA, 2002). The total amount of financial support that Japan provided was 60 billion yen, while the Brazilian government provided 33.3 billion yen, making the total for the entire project 93.3 billion yen. It is difficult to correctly estimate how much of the total investment the JIRCAS provided, because what JIRCAS contributed covered and extended to many miscellaneous areas. If information on all those activities by JIRCAS is correctly accumulated, it may be possible to evaluate JIRCAS' monetary contribution. Even if JIRCAS' contribution was only $1 \%$ of the total Japanese investment, the benefits of JIRCAS' contribution to the Japan could be as much as 124 million yen from soybeans, soybean-meal and -oil in 2016. Such benefits started in the mid-1990s and continue now and will in the future, and, as mentioned above, the JIRCAS contribution should have been extended to livestock. It has to be taken into consideration that there are some private sectors that financially invested in the agricultural development in Cerrado.

The Japan/Brazil Cerrado development project contributed to Japan's food security generating stable and lower prices for food imports to Japan, and Japanese consumers are beneficiaries as well. Such benefits are not confined to the donor country (Japan) but extend to the consumers in the rest of the world. This proclaims that financial aid like the ODA project by donor countries appear to be a sacrifice for the donor countries; however, the donor countries may get much more than they sacrificed along with the benefits to the rest of the world, and the total benefits are enormous in terms of money and food security if the project becomes successful.

The USAID (US Agency for International Development), the institute for the US ODA implementation, has set up some evaluation criteria for foreign aid programs. The criteria evaluates Effectiveness, Efficiency, Impact, Sustainability, and Relevance of the recipient, where the project is conducted. The criteria does not include any benefits to the donor (Office of the Director of U.S. Foreign Assistance, 2009). The USAID modified the criteria according to the new law, the Foreign Aid Transparency and Accountability Act, which was enacted in July 2016. However, the new criteria still does not include any benefits to the donor (USAID, 2018 and Grimm, 2018). Furthermore, Lawson (2016) 
reported that the evaluation criteria in the USAID lacks consistency during the last few decades.

In Japan, academic reports on the economic benefits to the donors are few. The benefits of the recipient from the project should be respected first. However, it should not be neglected that there may be secondary benefits, possibly a considerable amount of monetary benefits, to the donors if the project succeeds. The success of the Cerrado project encourages us to conduct more and continuous researches to evaluate the donor's benefit from foreign aid programs.

\section{AUTHOR CONTRIBUTIONS}

S. Ito organized the whole research as the leader and visited Cerrado, Brazil two times to collect data then wrote a draft for the manuscript.

J. Qian assisted Ito to organize the research program and conducted the econometric analysis as well as acted as the corresponding author.

N. Hassanzoy joined the research organizing the whole research and assisted for writing the manuscript.

\section{ACKNOWLEDGEMENTS}

This research was partially supported by the Food and Nutrition Balance of the JIRCAS (D1) during 2017 and 2018. Some assistance from Mr. Kengo Momohara, Ms. Naomi Oshige, and Mr. Masahiro Tanaka is acknowledged.

\section{REFERENCES}

Companhia Nacional de Abastecimento (Conab, 2017): a data source for agricultural productions by state, Visited on December 12, 2017, http://www.conab.gov.br/

Food and Agriculture Organization (FAO, 2010): Statistical Yearbook 2010, visited during November 2011 and May 2015: http://www.fao.org/docrep/015/am081m/am081m00.htm

Food and Agriculture Organization (FAO, 2018): FAOSTAT, visited on February 26, 2018

http://www.fao.org/faostat/en/\#data/TP

Grimm, Sherrie (2018): Interviewed at USAID Headquarter in Washington on January 3, 2018

Hongo, Yutaka and Akio Hosono (2012): A Miracle of Cerrado Development, Diamond Big Publishing Co. (『ブラジルの不毛の 台地「セラード」開発の奇跡』、ダイヤモンドビッグ社）

Instituto Brasileiro de Geografia e Estatística (IBGE, 2011): "Sistema IBGE de Recuperacao Automatica (SIDRA)": http:// www.sidra.ibge.gov.br/, visited during August 2011

International Monetary Fund (IMF, 2011): IMF Primary Commodity Prices:

http://www.imf.org/external/np/res/commod/index.aspx, visited during November 2011

Ito, Shoichi, Nguyen Hung Cuong, Takashi Kubo, and Chandaworn Bounnad (2009): Characteristics of International Grain Price Movements under the High Oil Prices, Journal of Rural Problems, 45-2, pp. 191-6

Ito, Shoichi (2017): "Food Statistics and Graphics" a web for the global food:

http://worldfood.apionet.or.jp/graph/index.html visited in December 2017

Ito, Shoichi (2017): "International Prices for Rice, Wheat, Corn and Soybeans" a web:

http://worldfood.apionet.or.jp/pricechart/Indexriceprice.html visited in December 2017

JICA (Japan International Cooperation Agency) (2002): JapanBrazil Cerrado Agricultural Development Project, Joint Evaluation, General Report ( in Japanese: 「日伯セラード農業開 発協力事業·合同評価調查·総合報告書」、農調投) JR01-58

Koizumi, T. (2014): Biofuels and Food Security in Brazil, Chapter 2 in Biofuels and Food Security: Biofuel Impact on Food Security in Brazil, Asia and Major Producing Countries by Tatsuji Koizumi, Springer (visited on February 25, 2018) http://www.google.co.jp/url?sa=t\&rct=j\&q=\&esrc=s\&source=we b\&cd=5\&ved=0ahUKEwili5mvhcHZAhVEzbwKHWujC2MQFghS MAQ\&url=http $\% 3 \mathrm{~A} \% 2 \mathrm{~F} \% 2 \mathrm{Fwww}$.springer.com $\% 2 \mathrm{Fcda} \% 2 \mathrm{Fcon}$ tent\%2Fdocument\%2 Fcda_downloaddocument \%2F9783319056449-c2.pdf\%3FSGWID\%3D0-0-45-1456812p176652226\&usg=AOvVaw0pVNjempFVIMNbTyV_B4FE http://www.springer.com/978-3-319-05644-9

Lawson, Marian Leonardo (2016): Does Foreign Aid Work? Efforts to Evaluate U.S. Foreign Assistance, Congressional Research Service, visited on January 10, 2018. https://fas.org/sgp/crs/row/R42827.pdf

Ministry of Agriculture, Livestock and Food Supply, Government of Brazil (MALFS, 2012): Brazilian Agricultural Foreign Trade, 2012 Edition, (p.21), www.brasilglobalnet.gov.br/... PUBEstudosComExtMAPAI2012.pdf , visited during January 2015

Mizobe, Tetsuo (2014): "Value Chain of Soybean Products in Cerrado, Brazil - An Enlarging Value Process from Soybean Products to Broiler" in Journal of agricultural development studies, 25(1), pp. 47-53 (「ブラジル・セラード地帯におけるダイ ズ製品のバリューチェーン：ダイズ製品から鶏肉に至るまでの価額拡 大プロセスー」『開発学研究』)

Norinchukin Research Institute, Japan (2008): "Brazil Moving toward the Largest Agricultural Exporter - Focusing on Development of Cerrado areas and Grain Dealers" in September issue of Journal of Norinkinyu, September 2008 (世界最大の農 産物輸出国に向かうブラジル——セラード開発と穀物メジャーの役割 を中心に一、、農林金融 $2008 \cdot 9$ )

Office of the Director of U.S. Foreign Assistance (2009): Evaluation Guidelines for Foreign Assistance, visited on January 4, 2018. http://pdf.usaid.gov/pdf_docs/Pnado818.pdf

US Agency for International Development (USAID, 2018): Evaluation, visited on January 9, 2018. https://www.usaid.gov/evaluation

US Department of Agriculture (USDA, 2011): PSD Online, http://apps.fas.usda.gov/psdonline/psdDownload.aspx, visited during December 2017,

US Department of Agriculture (USDA, 2013): U.S. Agricultural Trade, 2013, visited during January 2015:

http://www.ers.usda.gov/topics/international-markets-trade/usagricultural-trade.aspx

US Energy Information Administration (EIA, 2011): "Petroleum \& Other Liquids" West Texas Intermediate (WTI), visited during November 2011 and May 2015:

http://www.eia.gov/dnav/pet/hist/LeafHandler. ashx?n=PET\&s=RCLC1\&f=D

Yan, Shuqin, Kolawole Ogundari, Zhengwei Cao, Shoichi Ito, Hiroshi Isoda and Hisamitsu Saito (2015): "Study on the Contemporary Relationship between International and Domestic Grain Prices in Developing Countries: Focusing on Long Run and Short Run," Japanese Journal of Agricultural Economics, Vol. 17, pp. 64-69

APPEMDIX 1: Estimates for the Impacts of the Cerrado Development on Japan

In this section, a research done by the same authors in 2010 is reported. The method and data sources are exactly the same, however, the annual data employed only goes up to 2009. However, more agricultural products are included in this Appendix. The exchange rate 
was 80 yen per US dollar and the volume of production was smaller. It may be a good use for a comparison to review the 7 year time difference and to see the situation in other crops that the most recent research did not include.

In the research of this Appendix, the agricultural products included were soybeans, soybean-meal, corn, wheat, cotton, beef, pork, broiler, and coffee beans, which are all produced in Cerrado. Appendix Table 1 shows the shares of Cerrado in Brazil as well as relative to the global total production in 2009. The share of soybeans in Cerrado was 17\% in 2009 (Appendix Table 1), while it was $20 \%$ in 2016 . The production of soybeans, for example, increased significantly.

Regarding the economic impact of Cerrado on Japan in 2009, the Japanese benefits were estimated to be as much as 162.3 million dollars (13 billion yen) in the case of soybeans. For corn, of which Japan imported nearly 16 million tons in 2009, which is a common level of corn imports for Japan nowadays, Japan was estimated to have benefitted by 100.3 million dollars. Certainly, the corn imports have mainly been from the U.S.; however, increases in corn production in Cerrado surely influenced the global market prices.

When it comes to beef, whose elasticity of market price to production is as large as -3.55 , Japan must have benefitted by 585.5 million dollars. In the case of coffee beans, which has a large elasticity at -3.38 , and Cerrado share was increased to $25 \%$ of the global total production, Japan possibly gained over 1 billion dollars in 2009 relative to the situation where there was no such production in Cerrado (Appendix Table 2).

Appendix Table 1. Share of agricultural production in Brazil and Cerrado, 2009

\begin{tabular}{|c|c|c|c|c|c|}
\hline & $\begin{array}{c}\text { Share of Cerrado in } \\
\text { Brazil } / 1, \%\end{array}$ & $\begin{array}{c}\text { Global production/2 } \\
1000 \mathrm{MT}\end{array}$ & $\begin{array}{l}\text { Production in } \\
\text { Brazil/2 1000MT }\end{array}$ & Shares of Brazil & $\begin{array}{c}\text { Shares of Cerrado } \\
\text { to the world }\end{array}$ \\
\hline Soybeans & $66 \%$ & 260,854 & 69,000 & $26 \%$ & $17 \%$ \\
\hline Sybn Meal/3 & $\underline{66 \%}$ & 165,249 & 26,120 & $16 \%$ & $10 \%$ \\
\hline Corn & $53 \%$ & 819,607 & 56,100 & $7 \%$ & $4 \%$ \\
\hline Wheat & $5 \%$ & 684,306 & 5,026 & $1 \%$ & $0 \%$ \\
\hline Cotton & $98 \%$ & 101,337 & 5,450 & $5 \%$ & $5 \%$ \\
\hline Beef/ 4 & $\underline{56 \%}$ & 57,148 & 8,935 & $16 \%$ & $9 \%$ \\
\hline Pork/4 & $\underline{56 \%}$ & 100,405 & 1,130 & $3 \%$ & $2 \%$ \\
\hline Broiler/4 & $\underline{56 \%}$ & 74,308 & 11,023 & $15 \%$ & $8 \%$ \\
\hline Coffee Beans & $62 \%$ & 133,623 & 53,300 & $40 \%$ & $25 \%$ \\
\hline
\end{tabular}

Sources:/1: IG BE in Brazil.

/2: from USD A: PSD Online for 2009.

13: Same rate as the soybeans.

/4: Weighted average between soybean meal and corn for meats due to feeding.

Appendix Table 2. Economic impacts of agricultural development in Cerrado, Brazil and benefits to Japan in 2009

\begin{tabular}{|c|c|c|c|c|c|c|c|c|c|}
\hline & Soybean & Corn & Wheat & Cotton & Sybn Meal & Beef & Pork & Broiler & Coffee Bn \\
\hline Estimated elasticities & -0.175 & -1.03 & -1.94 & -1.15 & -0.55 & -3.55 & -2.38 & -0.329 & -3.38 \\
\hline Share of products in Cerrado & $17 \%$ & $4 \%$ & $0 \%$ & $5 \%$ & $10 \%$ & $9 \%$ & $2 \%$ & $8 \%$ & $25 \%$ \\
\hline Global prices in 2016, \$/MT & 385 & 167 & 227 & 1,408 & 366 & 2,684 & 1,251 & 1,927 & 3,177 \\
\hline $\begin{array}{l}\text { Increases in global prices if no } \\
\text { production in Cerrado, } \%\end{array}$ & $12 \%$ & $4 \%$ & $0 \%$ & $6 \%$ & $6 \%$ & $31 \%$ & $4 \%$ & $3 \%$ & $83 \%$ \\
\hline $\begin{array}{l}\text { Increases in global prices if no } \\
\text { production in Cerrado, } \$ / \mathrm{MT}\end{array}$ & 47.72 & 6.28 & 0.18 & 85.48 & 20.85 & 840.02 & 52.34 & 52.87 & $2,648.41$ \\
\hline Imports to Japan, $1000 \mathrm{MT}^{1}$ & 3,401 & 15,979 & 5,502 & 304 & 2,106 & 697 & 1,138 & 645 & 390 \\
\hline $\begin{array}{l}\text { Grains to Japan from ag. } \\
\text { Development in Cerrado, } \$ / \mathrm{MT}\end{array}$ & 162.3 & 100.3 & 1.0 & 26.0 & 43.9 & 585.5 & 59.6 & 34.1 & $1,032.9$ \\
\hline $\begin{array}{l}\text { Ditto, in Japanese yen, billion yen, } \\
107.84 \text { yen/USD }{ }^{2}\end{array}$ & 13.0 & 8.0 & 0.1 & 2.1 & 3.5 & 46.8 & 4.8 & 2.7 & 82.6 \\
\hline
\end{tabular}

